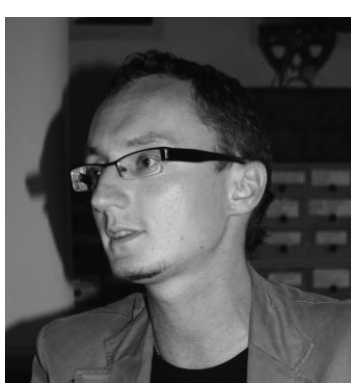

\title{
Tomasz Pudłocki
}

Tomasz Pudłocki - doktor nauk humanistycznych w zakresie historii, adiunkt w Zakładzie Historii Oświaty i Kultury Uniwersytetu Jagiellońskiego, prezes Towarzystwa Przyjaciół Nauk w Przemyślu. Zainteresowania badawcze: historia kultury Europy Środkowej XIX i XX w., mikrohistoria, gender studies. Autor kilkudziesięciu artykułów i dwóch monografii: Blask szarości... Życie codzienne w I Państwowym Gimnazjum im. Juliusza Słowackiego w Przemyślu w latach 1918-1939 (2004); Iskra światła czy kopcaca pochodnia? Inteligencja w Przemyślu w latach 1867-1939 (2009). 


\section{„Wadą niepozbywalną jest jego nerwowość" - Stefan Grabiński jako nauczyciel Seminarium Nauczycielskiego Męskiego we Lwowie w latach 1921-1929}

dotychczasowych pracach o Stefanie Grabińskim mało poświęcano mu miejsca jako nauczycielowi (TLSG, s. 71). W literaturze przedmiotu Grabiński funkcjonuje nade wszystko jako pisarz. Tymczasem głównym źródłem jego utrzymania było nauczycielstwo. O ile okres pracy w I Gimnazjum w Przemyślu został już omówiony w miarę wyczerpują$\mathrm{co}^{1}$, o tyle materiały zgromadzone w Centralnym Państwowym Historycznym Archiwum Ukrainy we Lwowie pozwalają na przybliżenie nieznanych dotychczas kart z życia poety okresu jego pracy we lwowskim Państwowym Seminarium Nauczycielskim Męskim.

Grabiński starał się o przeniesienie służbowe z Przemyśla do Lwowa przez dłuższy czas. Nad Sanem pracował kilka lat. Będąc zastępcą nauczyciela w filii IV Gimnazjum we Lwowie, został decyzją Rady Szkolnej Krajowej z 13 VII 1917 przeniesiony na to samo stanowisko do Gimnazjum z wykładowym językiem polskim w Przemyślu². W tym czasie jego talent pisarski na tyle się rozwinął, że zaczął szukać sposobności powrotu do Lwowa, który gwarantował mu szersze kontakty i możliwości rozwoju twórczego niż prowincjonalny Przemyśl. Jednak dopiero decyzją z 16 III 1921 Kuratorium Okręgu Szkolnego Lwowskiego przychyliło się do jego prośby, mianując go nauczycielem w Państwowym Seminarium Nauczycielskim Męskim we Lwowie ${ }^{3}$.

Według Artura Hutnikiewicza Grabiński traktował swoją pracę nauczyciela tylko jako źródło utrzymania ${ }^{4}$. Pomimo iż we wcześniejszym artykule dotyczącym biografii Grabińskiego byłem skłonny zgadzać się z tą tezą́, to dokładniejsza analiza materiałów archiwalnych, zwłaszcza znajdujących się we lwowskim Centralnym Archiwum, zmusza do zrewi-

1 T. Pudłocki, Przemyski okres w życiu Stefana Grabińskiego, „Rocznik Przemyski” 2006, z. 3, „Literatura i Język", s. 71-86.

2 Sprawozdanie Dyrekcji c.k. Gimnazjum z wykładowym językiem polskim w Przemyślu za r. szk. 1917/1918, Przemyśl 1918, s. 5.

${ }_{3}^{3}$ Centralne Państwowe Historyczne Archiwum (dalej CDIAU) we Lwowie, fond 179 opis 3 sprawa 514.

${ }^{4}$ List A. Hutnikiewicza do T. Pudłockiego, Toruń, 22 IV 2003.

${ }_{5}$ T. Pudłocki, op. cit. 
dowania poglądów. Trudno bowiem zgodzić się z tezą Hutnikiewicza, wziąwszy pod uwagę bardzo dobre przygotowanie pisarza do zawodu nauczyciela oraz wysokie wymagania, jakie stawiał uczniom ${ }^{6}$. Co więcej, warto przypomnieć, że Hutnikiewicz był uczniem Grabińskiego w VI Gimnazjum we Lwowie, w którym pisarz miał tylko dodatkowe godziny - podstawowy wymiar w ramach etatu realizował w Seminarium Nauczycielskim Męskim. Nie dziw zatem, że Grabiński w szkole, która stanowiła dla niego tylko dodatkowe źródło utrzymania, mniej przykładał się do zajęć.

Przeniesienie do Seminarium Męskiego zainicjowało tryumfalny powrót pisarza nad Pełtew. Stanisław Maykowski, który jak Grabiński wcześniej pracował w przemyskim gimnazjum, umożliwił mu druk nowel na łamach najpoczytniejszej lwowskiej gazety - „Słowa Polskiego". Ukazały się w tym czasie Bialy wyrak. Gawęda kominiarska (1921, R. 26, nr-y 453-456, wszędzie na s. 5), a także Gebrowie (nr-y: 494 s. 5; 495, s. 7; 497, s. 7; 498, s. 5; 499, s. 5; 500, s. 5)7. Obie nowele weszły później do tomu Ksiegga ognia. Nowele (Łódź 1922). Z kolei w 1922 roku „Słowo” wydrukowało jego nowelę Dziwna stacja (Fantazja przyszłości) - (1922, R. 27, nr 54, s. 3, nr-y: 55-59 - wszędzie s. 5, nr 60, s. 4-5)8 oraz Czarna Wólka, którą pisarz zadedykował znanemu krytykowi literackiemu i poecie, Józefowi Jedliczowi (nr 250, s. 5; nr 251, s. 7; nr 252, s. 5; nr 253, s. 2, nr-y: 254-256 wszędzie s. 5)9. Wreszcie na łamach „Słowa” Maykowski zrecenzował pochlebnie wieczór autorski Grabińskiego, urządzony 29 XI 1921 r. w Związku Literatów Polskich.

Twórczość Stefana Grabińskiego - mówił p. J. Jedlicz - na gruncie polskiej beletrystyki jest zjawiskiem niezwykłym. Autor zbiorów nowel: Na wzgórzu róż, Demon ruchu, Szalony Pątnik, dramatu Willa nad morzem - realizuje i reprezentuje pierwszy w naszej literaturze czysty typ twórczości fantastycznej. Jako taki spełnia u nas rolę i misję pioniera nowego „genre’u” literackiego $[\ldots]^{10}$.

Podczas wieczoru przemawiał znany krytyk literacki i poeta Józef Jedlicz, a aktor Barwiński czytał dwie nowele pisarza Pożarowisko i Gebrowie. Maykowski zapisał:

Obie te nowele należą do cyklu: Księga Ognia, w obu ogień jest głównym motywem. Właśnie ten fakt można zapisać na minus wtorkowego spotkania. W interesie urozmaicenia słuchaczom wrażeń [powinno się było] dać rzeczy silniej kontrastowe. Mimo to wrażenie oryginalnych w pomyśle, a doskonale skonstruowanych nowel było wielkie ${ }^{11}$.

Prawdopodobnie sukces literacki i ciepłe przyjęcie przez sfery intelektualne Lwowa „osłodzily" poecie rozczarowanie nowym miejscem pracy. Wziąwszy bowiem pod uwagę specyfikę nowej szkoły, trudno uznać, by posada polonisty w tym seminarium była spełnieniem jego ambicji zawodowych.

${ }^{6}$ Zob. Archiwum Państwowe w Przemyślu, zesp. 387, sygn. 128-130; CDIAU we Lwowie, fond 179, opis 3, sprawa 1165-1166.

${ }^{7}$ A. Hutnikiewicz nie uwzględnił ich wśród utworów rozproszonych Grabińskiego (TLSG, s. 466-467).

8 Nowela ta nie weszła do edycji książkowych Grabińskiego; nie wymienił jej A. Hutnikiewicz wśród utworów rozproszonych (TLSG, s. 465-467).

9 A. Hutnikiewicz wymienia Czarnq Wólkę jako drukowaną tylko w warszawskich „Wiadomościach Literackich" (TLSG, s. 466)

10 S. Maykowski, Wieczór autorski Stefana Grabińskiego urządzony w Zwiq̨zku Literatów Polskich, „Słowo Polskie" 1921, nr 489, s. 5.

11 Ibidem. 
W Gimnazjum Słowackiego w Przemyślu Grabiński miał świetne warunki lokalowe do pracy, dobrych, choć wymagających dyrektorów i pracował pomiędzy ludźmi z uniwersyteckim wykształceniem, którzy stanowili elitę intelektualną miasta. Wielu z nich było czołowymi animatorami życia kulturalno-naukowego Przemyśla. Pozycja Grabińskiego, uznanego już wtedy wschodzącego pisarza, wśród nich była niebagatelna ${ }^{12}$. Seminarium lwowskie w żaden sposób nie przypominało poprzedniego miejsca pracy i mogło być dla pisarza dużym rozczarowaniem.

Przede wszystkim warunki pracy były kiepskie. Raz po raz podczas konferencji nauczycielskich narzekano na niewygodny, za mały i fatalny pod względem higienicznym budynek. Jak pisano:

Pomieszczenie jest jak najfatalniejsze. Pomijając już szczupłość sal (niektóre 2,5×2,5, 3×3), kręte schody, brak światła, korytarzy, podwórza, sali gimnastycznej, sali rysunkowej, budynek wprost ze względu na niebezpieczeństwo życia nie nadaje się na pomieszczenie szkoły ${ }^{13}$. [ ... ]

W niektórych klasach brak klamek, kilka szyb jest wybitych; w wychodkach koniecznie trzeba naprawić przerdzewiałe pływaki. Przed budynkiem jest błoto, a podanie do Magistratu o zajęcie się wyszrutowaniem chodnika pozostało bez odpowiedzi. W dni deszczowe młodzież brnie w błocie i wnosi błoto do klas. [... ] ilość opału dla zakładu jest niewystarczająca ${ }^{14}$.

Szkoła mieściła się w trzypiętrowej kamienicy przy ul. Nabielaka 67 i była własnością Adama i Anieli Didurów. Ponadto przy ul. Listopada 6 wynajmowano dwie sale (jako pracownię rysunków i salę gimnastyczną) w internacie im. G. Piramowicza ${ }^{15}$. Obowiązkowe dla uczniów i nauczycieli (a więc i dla Grabińskiego) nabożeństwa odbywały się do końca roku szkolnego 1921/22 w sali gimnastycznej szkoły kupieckiej, a od września 1922 r. w kościele św. Elżbiety. Seminarium nie miało jednak w świątyni godziny wyznaczonej tylko dla siebie. Stąd nauczyciele skarżyli się, że równocześnie przy bocznych ołtarzach odbywały się msze św. dla innych szkół, cisnęli się ludzie i był duży gwar. Dlatego wychowawcy (do których w pierwszych latach pracy należał również Grabiński) przed egzortą wygłaszaną przez katechetę nie mieli warunków nawet do przeczytania nazwisk uczniów z katalogów klasowych, a cóż dopiero mówić o właściwym nadzorze nad młodzieżą ${ }^{16}$.

Początki pracy nie zapowiadały się najgorzej. Grabiński musiał jeszcze w sierpniu 1921 roku, zaraz po przeprowadzce, zgłosić się do dyrekcji szkoły i złożyć przysięgę służbową. 1 września odbyła się jego pierwsza w nowym miejscu pracy konferencja plenarna pod przewodnictwem kierownika Józefa Jastrzębskiego. Jak zanotowano w sprawozdaniu z konferencji, kierownik „wyraża nadzieję, że nowo przybyli koledzy zżyją się z gronem i przyczynią się do stworzenia w Zakładzie atmosfery ciepłej i przyjaznej”"17.

12 Zob. T. Pudłocki, op. cit. Zob. też: idem, Blask szarości. Życie codzienne w I Państwowym Gimnazjum im. Juliusza Słowackiego w Przemyślu w latach 1918-1939, Przemyśl 2004; idem, Iskra światła czy kopcąca pochodnia? Inteligencja w Przemyślu w latach 1867-1939, Kraków 2009.

${ }^{13}$ CDIAU, fond 179, opis 3, sprawa 1166.

14 Ibidem, sprawa 1165.

15 CDIAU we Lwowie, fond 179, opis 3, sprawa 1166.

16 Ibidem, sprawa 1165.

17 CDIAU, fond 179, opis 3, sprawa 1165. 
Grabiński w pierwszym roku pracy dostał 22 godziny tygodniowo, ucząc języka polskiego na kursach: I a (4 h), II b (4 h), III (4 h), IV a (5 h), IV b (5 h) ${ }^{18}$. Dodatkowo zlecono mu sześć godzin pracy wychowawczej i dwie w bibliotece nauczycielskiej. Łącznie miał więc 30 godzin tygodniowo, czyli dużo. Powierzono mu wychowawstwo kursu III, na który uczęszczało 42 uczniów. Nowe grono kolegów nauczycieli, wśród których przyszło mu pracować, należało do przeciętnych. Trudno wskazać na jakąś wybitną postać wśród nich ${ }^{19}$. Także i inni poloniści, Antoni Haluza, a po jego szybkim przeniesieniu Władysław Starzecki i od roku szkolnego 1922/23 nowy dyrektor, Kazimierz Zimmerman (z wykształcenia filolog polski), nie wyróżniali się niczym pośród licznych we Lwowie nauczycieli szkół średnich.

Warto podkreślić, że Grabiński był jednym z najlepiej wykształconych nauczycieli w szkole ${ }^{20}$. Nawet pobieżne przeglądnięcie wykładów, na które uczęszczał, pozwala wyciągnąć wniosek, że Grabiński należał do studentów nie tylko pracowitych, ale nad wyraz obytych w stosunkach uniwersyteckich. Wszak był słuchaczem czołowych profesorów Wydziału Filozoficznego Uniwersytetu Lwowskiego: Józefa Kallenbacha, Wilhelma Bruchnalskiego, Bronisława Kruczkiewicza, Stanisława Witkowskiego, Tadeusza Sinki, Kazimierza Twardowskiego, Mścisława Wartenberga, Bolesława Mańkowskiego ${ }^{21}$. Wśród jego kolegów

${ }^{18}$ Według ówczesnej nomenklatury uczniowie w seminariach nauczycielskich chodzili na kursy, nie do klas.

19 Grabiński rozpoczynał pracę, kiedy grono uczących w r. szk. 1921/22 tworzyli: dyrektor Józef Jastrzębski (lekcje praktyczne, matematyka), Antoni Haluza (język polski, ukraiński), Karol Chomicki (język niemiecki), Michał Chrupowicz (język ukraiński), Józef Dąbrowski (historia, zajęcia w szkole ćwiczeń), Stanisław Jachnowicz (przyrodoznawstwo, gospodarstwo wiejskie, ćwiczenia praktyczne), Stanisław Kubrakiewicz (rachunki, zajęcia w szkole ćwiczeń), Stanisław Ligęza (roboty ręczne), Józef Lubczyński (zajęcia w szkole ćwiczeń), Kazimierz Łotocki (rysunki), Władysław Orosz (przyrodoznawstwo, zajęcia w szkole ćwiczeń), ks. Józef Paluch (religia, zajęcia w szkole ćwiczeń), Aleksander Saloni (geografia, historia), Teofil Szumański (geografia), Henryk Slawiczek (fortepian), Michał Szczupaczkiewicz (skrzypce, śpiew), Józef Szajkowski (matematyka), dr Władysław Wyhowski (higiena).

${ }_{20}$ Taki wniosek pozwala wyciągnąć m.in. lektura protokołów jego egzaminów nauczycielskich, zob. CDIAU, fond 174, opis 1, sprawa 490. Zob. też: T. Pudłocki, Przyczynek do biografii Stefana Grabińskiego, „Rocznik Przemyski” 2009, z. 3, „Literatura i Język", s. 139-146.

${ }_{21}$ Dla przykładu w półroczu letnim 1907/1908, będąc na VI kursie, Grabiński słuchał następujących wykładów: Józefa Kallenbacha: Literatura polska za Sasów (3 godziny tygodniowo), Rozkwit romantyzmu w Polsce cz. 2 (2 godziny tygodniowo) oraz uczęszczał na jego Seminarium filologii polskiej (2 godziny tygodniowo); Wilhelma Bruchnalskiego: Historia literatury polskiej w epoce odrodzenia (2 godziny tygodniowo), Nauka form języka polskiego. Il koniugacja (3 godziny tygodniowo) oraz uczęszczał na jego Seminarium literatury polskiej staropolskiej (2 godziny tygodniowo); Konstantego Wojciechowskiego - Nowożytny romans polski (2 godziny tygodniowo); Bronisława Kruczkiewicza: O administracji państwa rzymskiego (5 godzin tygodniowo) oraz uczęszczał na jego Proseminarium filologii greckiej (2 godziny tygodniowo); Stanisława Witkowskiego: Historia wymowy greckiej (2 godziny tygodniowo), Dialekt joński (2 godziny tygodniowo), Historia języka greckiego po Aleksandrze Wielkim (1 godzina tygodniowo), Platona "Sympozjum" (4 godziny tygodniowo) oraz uczęszczał na jego proseminarium z filologii łacińskiej (2 godziny tygodniowo); Tadeusza Sinki - Lukian i jego czasy (3 godziny tygodniowo); Ignacego Zakrzewskiego - Dzieje Polski cz. 2 (3 godziny tygodniowo); Adama Antoniego Kryńskiego: Objaśnienia zabytków języka staropolskiego (2 godziny tygodniowo), Gramatykę języka starosłowiańskiego (2 godziny tygodniowo), Objaśnienia języka starosłowiańskich zabytków (1 godzina tygodniowo). W półroczu zimowym r. akad. 1908/1909, będąc na VII kursie, uczęszczał na następujące zajęcia: J. Kallenbacha: Literatura polska za Sasów (3 godziny tygodniowo), Rozkwit romantyzmu w Polsce cz. 3 (2 godziny tygodniowo) oraz uczęszczał na jego Seminarium filologii polskiej (2 godziny tygodniowo); W. Bruchnalskiego: Historia literatury polskiej w epoce odrodzenia (2 godziny tygodniowo), Głosowniajęzyka polskiego (2 godziny tygodniowo), Zarys wierszowania polskiego (2 godziny tygodniowo); B. Kruczkiewicza: Gramatyka łacińska (2 godziny tygodniowo), Proseminarium greckie (2 godziny tygodniowo); S. Witkowskiego: Proseminarium łacińskie. Podczas ostatniego semestru studiów, tj. VIII kursu w semestrze letnim r. akad. 1908/1909 uczęszczał na zajęcia do: J. Kallenbacha, Czasy Stanisława Augusta (3 godziny tygodniowo), Dramaturgia Juliusza Słowackiego (2 godziny tygodniowo), Seminarium filologii polskiej (2 godziny tygodniowo); W. Bruchnalskiego: Historia literatury polskiej od czasów najdawniejszych do odrodzenia (2 godziny tygodniowo), Głosownia języka polskiego (2 godziny tygodniowo), Zarys wierszowania polskiego (2 godziny tygodniowo), B. Kruczkiewicza: Życie prywatne Rzymian (3 godziny tygodniowo); Prose- 


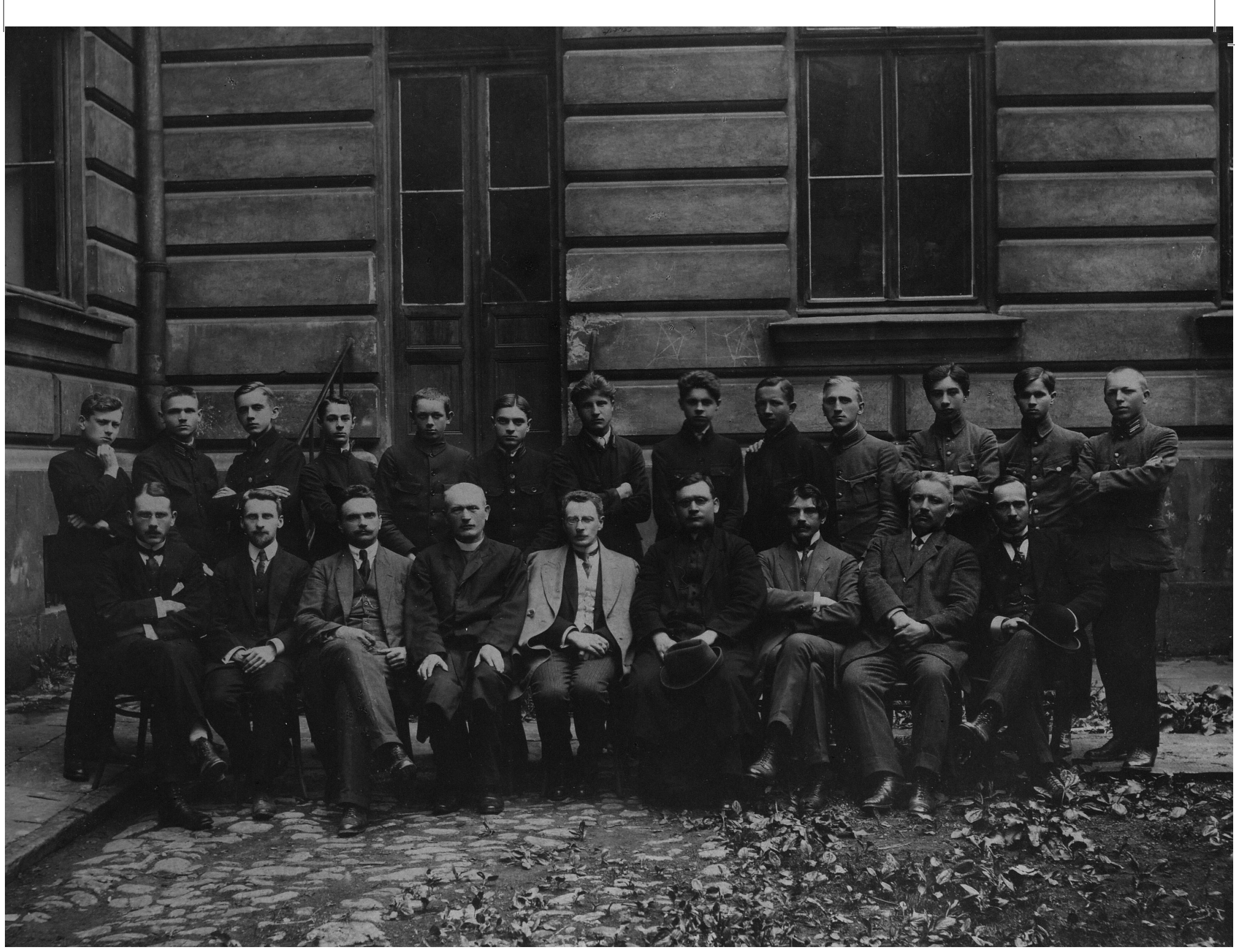

\section{Grono nauczycielskie I Państwowego Gimnazjum w Przemyślu z uczniami klasy I b, wrzesień 1919 r.}

Od lewej siedzą: Franciszek Lorenz, Stefan Grabiński, Zygmunt Weimer, ks. Jan Sawczyn, kier. Zygmunt Skorski, ks. Jakub Szypuła, Apolinary Garlicki, Stanisław Węgrzyn, Stefan Oleksiewicz.

Ze zbiorów Archiwum Państwowego w Przemyślu 
z lawy studenckiej byli m.in. późniejsi profesorowie szkół wyższych, politycy, wojskowi i in., jak np.: Władysław Tarnawski, Czesław Mączyński, Stanisław Łempicki, Stanisław Kot, Zygmunt Klemensiewicz, Juliusz Kleiner, Maciej Rataj, Edward Rydz-Śmigły, Kazimierz Świtalskii ${ }^{22}$. Trudno powiedzieć, czy wśród kolegów, uczących, jak i w seminarium lwowskim Grabiński nawiązał jakieś przyjaźnie. De facto poza nim oraz bardzo krótko uczącymi dr. Mojżeszem Schorrem i dr. Denysem Łukianowyczem żaden z nauczycieli się nie wyróżniał. Prawdopodobnie więc i umysłowością koledzy musieli mu znacznie ustępować, choć większość posiadała wykształcenie uniwersyteckie (według ówczesnych wymogów niezbędne do pracy w szkolnictwie średnim). Inna rzecz, że w Przemyślu Grabiński znalazł się w środowisku ludzi, których znał z czasów lwowskich (choćby ze studiów), spotykając się z nimi podczas wykładów. Należeli do nich tacy nauczyciele, jak m.in.: dr Władysław Tarnawski, Anna Fischerówna, Maksymilian Brandler, Andrzej Skowronek ${ }^{23}$. Szybko nawiązał też szczere, długoletnie przyjaźnie, również pośród członków grona nauczycielskiego I Gimnazjum. Mniejsze środowisko sprzyjało konsolidacji grupy i - sądząc po rozwoju literackim pisarza - bardzo Grabińskiemu pomagało. Czy w seminarium lwowskim pisarz znalazł pokrewne dusze wśród kolegów? Po przeprowadzce do Lwowa jedynie w pierwszym okresie Grabiński wciąż odnosił sukcesy, potem znalazł się niemal w powszechnym zapomnieniu. Do tego doszły jeszcze kłopoty zdrowotne pisarza i jego nie najlepszy stan psychiczny. Czy związane to było również z inercją umysłową środowiska nauczycielsko-uczniowskiego lwowskiego seminarium?

O Grabińskim jako nauczycielu sporo mówią krótkie sprawozdania pisane przez niego z przerobionego materiału, pracy wychowawczej oraz hospitacje jego lekcji przeprowadzane przez dyrektorów. Pod tym kątem biografia nauczycielska pisarza niczym nie wyróżnia się wśród innych, podobnych.

Grabiński jak inni nauczyciele regularnie zdawał sprawozdanie z przerobionego materiału. Tak pisał o tym, co zrobił w klasie II b w okresie 11 II-17 V 1922 r.: „Z gramatyki: Koniugacja i rozbiór zdania. Analiza i lektura Pana Tadeusza (ks. 8-12). Lektura wspólna Karpackich Górali (Korzeniowskiego) i Zemsty Fredry (ukończono)”. W klasie III przerobił w tym czasie: „Z gramatyki: głosownia, fleksja i rozbiór zdania. Z literatury: od czasów najdawniejszych do twórczości Karpińskiego. Analiza wspólna Makbeth'a i Ślubów Panieńskich. Prywatna lektura uczniów”. W obu klasach IV: „Literatura polska od wydania Kordiana Juliusza Słowackiego do r. 1848 (Romantyzm wycofano).Z gramatyki powtórzenie materiału z lat poprzednich”. Z tych krótkich zapisów sporządzonych osobiście przez Grabińskiego niewiele jeszcze wynika na temat tego, jakim był nauczycielem. Tymczasem już w pierw-

minarium filologii greckiej (2 godziny tygodniowo); S. Witkowskiego: Literatura grecka epoki cesarstwa (2 godziny tygodniowo); Proseminarium filologii łacińskiej (2 godziny tygodniowo); K. Twardowskiego: Psychologia myślenia (4 godziny tygodniowo), Filozofia epoki odrodzenia (1 godzina tygodniowo); M. Wartenberga: Teoria poznania (3 godziny tygodniowo), Mechanizm i teleologie (2 godziny tygodniowo); B. Mańkowskiego: Zagadnienia pedagogiczne (3 godziny tygodniowo), Seminarium pedagogiczne (2 godziny tygodniowo); A. A. Kryńskiego: Objaśnianie zabytków języka staropolskiego (1 godzina tygodniowo), Gramatykę języka starorzymskiego (2 godziny tygodniowo); Józefa Schatza: Geschichte Grammatik der deutsche Sprache (3 godziny tygodniowo), Das Niebelungenlied (2 godziny tygodniowo); Ryszarda Wernera - Geschichte der deutschen Literatur (3 godziny tygodniowo). Zob. Państwowe Archiwum Obwodu Lwowskiego (dalej DALO), fond 26, opis 15, sprawa 617, 619, 620. Zob. szerzej: T. Pudłocki, Środowisko studenckie Stefana Grabińskiego, „Rocznik Przemyski” 2012, z. 2, „Literatura i Język", s. 133-144.

${ }^{22}$ Wszyscy wymienieni uczęszczali na podobne wykłady, niejednokrotnie stykając się z Grabińskim nie tylko podczas jednych zajęć, ale i kilku z nich - zob. DALO, fond 26, opis 15, sprawa 617, 619-620.

${ }_{23}$ DALO, fond 26, opis 15, sprawa 617. 
szym roku pracy dał się poznać jako pedagog wymagający i surowy. Na kursie II b dał 11 ocen niedostatecznych na koniec tego okresu, na III, gdzie był wychowawcą - aż 15 (na 42 uczniów), na obu kursach czwartych - po jednej ocenie niedostatecznej. Dla porównania polonista uczący na kursie II a dał tylko jedną dwóję. Również w roku 1923/24 Grabiński wypadał jako najostrzejszy ze wszystkich nauczycieli. W okresie 1 IX-23 X 1923 dał w III a - 10 ocen niedostatecznych, w III b - 14, w IV a - 8, w IV b - 12, w V - 8. Nawet nowy dyrektor, K. Zimmerman, również polonista, uczący w II b dał „jedynie” 6 ocen niedostatecznych. Z kolei w roku szkolnym 1926/27 liczba ocen niedostatecznych postawionych przez Grabińskiego jeszcze przeciętnie wzrosła: w I - 4 (uczył on na tym kursie historii), w III a - 10, III b - 13, IV - 12, IV b - 12, V - 13.

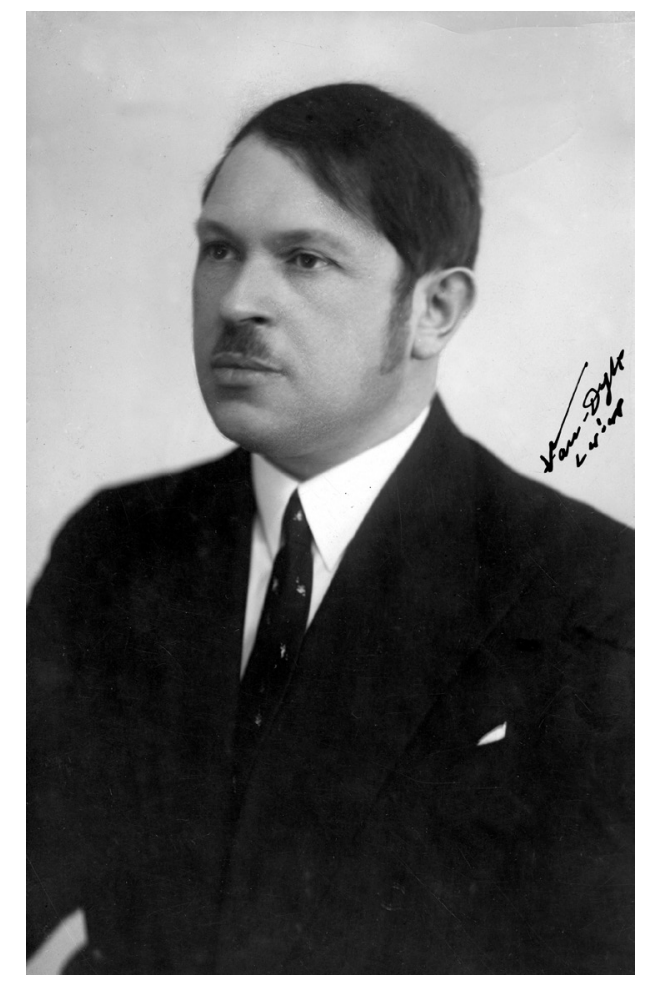

Wilam Horzyca (1889-1959), znajomy Grabińskiego, z którym pisarz dzielił wizję teatru monumentalnego. Ze zbiorów Narodowego Archiwum Cyfrowego

Czy tak słabe wyniki nauczania były jedynie winą nauczyciela, który nie potrafił zaciekawić uczniów przerabianym materiałem? Nie można wyciągnąć bardziej błędnego wniosku. Analiza wyników hospitacji dyrektorskich przeprowadzonych podczas lekcji Grabińskiego pozwala podważyć tezę Artura Hutnikiewicza, jakoby Grabiński traktował pracę nauczyciela jedynie dorywczo, nie przykładając się do niej. Szczęśliwie zachowało się kilka ocen Grabińskiego z różnych lat, dokonanych przez Kazimierza Zimmermana, który jako polonista najlepiej mógł ocenić kwalifikacje i zdolności pedagogiczne oraz przygotowanie merytoryczne swego podwładnego.

Między 1 IX a 23 X 1923 roku Zimmerman pięciokrotnie wizytował lekcje Grabińskiego. Dwa razy na kursie piątym oraz czwartym „a”. Dla lepszego zobrazowania oceny Grabińskiego jako nauczyciela pozwolę sobie na przytoczenie ich in extenso: 
Gramatyka. Powtarzano fonetykę, a mianowicie stopniowanie (szeregi) samogłosek, przy czym jako przykładów używano także wyrazów i form starosłowiańskich. Przykłady wyszukują i podają sami uczniowie przy pomocy nauczyciela. Niektóre z nich sprawiają pewne trudności, np. do wyrazu słowo, sława - dołączono teoretycznie skonstruowany wyraz słuć, do słowa rzec (reki-ti), rok = prorok, roki, rokować - wyraz: Arkana (= Rak-ona). W stopniowaniu nie wyczerpano szeregu e w kierunku zanikania samogłoski e (wrzekomy - wrzkomy w Grażynie). Robota jest klasowa, zajmująca, wszyscy uczniowie są wciągani do pracy.

Na tym samym kursie lekcja literatury. Synteza twórczości Słowackiego. Wyniki dobre, praca nauczyciela sumienna i rozumna. Przy swej inteligencji i gorliwości nauczyciel ten mógłby osiągnąć znacznie lepsze wyniki, gdyby miał młodzież więcej umysłowo rozwiniętą i mógł zapanować nad swą nerwowością ${ }^{24}$.

Powtórzenie i uzupełnienie lekcji Improwizacja Konrada; jako lekcja nowa Widzenie ks. Piotra. W związku z tym omówiono kwestię religijności (o ile przejawia się w temacie) i prometeizm. Powtórzenie było nieco pobieżne, gdyż wzięto za szeroki materiał. Gdy mowa o Prometeuszu nie dość było wzmianki o Ajschylosie, może należało rozszerzyć, przytoczyć w tłumaczeniu (J. Szujskiego) kilka scen (monologi Prometeusza, Prometeusz a Hermes) - a także uwzględnić prometeizm w literaturze europejskiej. Gdyby się temu tematowi poświęciło osobną lekcję, czas nie byłby stracony. Wszak horyzont myślowy naszych uczniów jest tak ciasny!

Nowa lekcja przeprowadzona była zupełnie dobrze; interpretacja Widzenia właściwa. Tłumaczenie "44” nie zajęło zbyt wiele czasu. Nauczyciel wspomniał o kilku hipotezach, ale nad nimi wiernie nie zatrzymywał się - i całkiem słusznie ${ }^{25}$.

Przerabiano jako lekturę domową Horsztyńskiego. Zdawało tylko kilku uczniów. Nauczyciel pyta nie tylko o treść, ale uwzględnia budowę dramatu, stosunek do innych dzieł poety itd., stara się o wniknięcie w intencje autora ${ }^{26}$.

Spostrzeżenia dyrektora Zimmermana z jesieni 1923 roku pozwalają szerzej spojrzeć na Grabińskiego jako nauczyciela. Owszem, dyrektor zarzuca mu nerwowość i może zbyt pobieżne przeprowadzenie lekcji powtórkowej, ale są to w istocie sprawy marginalne. Tak naprawdę Grabiński jawi się jako nauczyciel, który potrafił współdziałać z całym zespołem klasowym, angażując uczniów do pracy i zmuszając do samodzielnego myślenia. Odpowiednio organizował czas trwania zajęć i nawet skomplikowane kwestie językowo-gramatyczne potrafil przedstawić w sposób ciekawy.

O tym, że nie były to przypadkowe wnioski, świadczą notatki z innych hospitacji. W grudniu 1924 roku dyrektor wizytował lekcje na kursie piątym:

Początek Króla Ducha, inkarnacja, epizod: Wanda. Metoda heurystyczna. Lekcja prowadzona dobrze, nauczyciel umie obudzić zajęcie, podtrzymać uwagę. Grupowanie materiału według głównych myśli, odwoływanie się do rzeczy już poznanych, wyszukiwanie podobieństw w pomyśle i wykonaniu z innymi dziełami i poetami - wszystko to sprawia, że uczniowie z zajęciem śledzą tok akcji poematu. Wadą nauczyciela, której łatwo pozbyć się może, jest często używanie wyrazów obcych, wadą zaś „niepozbywalną” - to jego nerwowośćc ${ }^{7}$.

\footnotetext{
24 Dwie lekcje na kursie piątym.

25 Jedna godzina na kursie czwartym.

26 Jedna lekcja na kursie piątym. CDIAU we Lwowie, fond 179, opis 3, sprawa 1165.

27 Ibidem.
} 
Trudno oprzeć się wrażeniu, że Grabiński - doskonale przygotowany merytorycznie i pedagogicznie - był (wbrew temu, co napisał Hutnikiewicz) nauczycielem bardzo dobrym. Co więcej, starał się podciągać swoich uczniów intelektualnie, stąd może „wada”, którą zarzucił mu przełożony - nagminne używanie wyrazów obcych. Mogło to być jednak jego celowe postępowanie, by rozszerzać horyzonty myślowe swych podopiecznych, którzy - jak to wynika z notatek Zimmermana - do najbardziej lotnych nie należeli. A takie pochlebne opinie zdobywali nieliczni nauczyciele. Przykładowo drugi polonista szkoły, Władysław Starzecki, był oceniany dużo słabiej od Grabińskiego.

Ostatnia zachowana karta hospitacyjna pochodzi z 1926 roku i tylko potwierdza dotychczasowe spostrzeżenia: „Analiza Lilli Wenedy. Żywioły symboliczne, ideowy związek z Kordianem i Anhellim. Uczniowie orientują się dobrze. Lekcja nowa: Grób Agamemnona [cz. 1] - jako ideowo spokrewniony z Lilla Weneda. Metoda heurystyczna - użyta bardzo rozumnie; wrażenie korzystne" 28 .

„Nerwowość” Grabińskiego odnotowywana przez dyrektora musiała być jednak utrzymywana w ryzach, skoro mimo dużej liczby nauczycieli to właśnie jemu powierzano wychowawstwo klas przez szereg lat. W roku szkolnym 1921/22 był wychowawcą młodzieży kursu trzeciego. Z kolei w latach 1924/25-1926/27 prowadził młodzież jako wychowawca od kursu trzeciego do piątego, tj. do klasy maturalnej, a w latach 1927/28-1928/29 był wychowawcą dwóch ostatnich kursów. Niewiele można powiedzieć o Grabińskim jako wychowawcy. Zachowała się jedynie krótka notatka z 23 V 1922, w której pisarz „zdawał sprawę" ze swych czynności wychowawczych:

\begin{abstract}
Założona w I półroczu gmina klasowa funkcjonuje w dalszym ciągu. Wychowawca ponownie zorganizował samopomoc koleżeńską uczniów, której zadaniem [jest] udzielanie wskazówek w nauce uczniom mniej uzdolnionym. Odbyto wycieczkę do Galerii Narodowej Obrazów, zwiedzono Muzeum Lubomirskich i oglądano drzeworyty polskie z 18. wieku. Ponadto urządzono wycieczkę poza miasto. Wychowawca przeprowadził podwójną ankietę na temat życia pozaszkolnego i zajęć popołudniowych młodzieży. Wyniki ankiety i refleksje, jakie mu się nasunęly przy tej sposobności, podaje równocześnie w osobnym referacie ${ }^{29}$.
\end{abstract}

Niestety, referat ten nie zachował się, ale już samo sprawozdanie z czynności wychowawczych ujawnia nowe rysy Grabińskiego jako nauczyciela. Interesował się warunkami życia, jakie mieli jego uczniowie w domu, kwestią spędzania przez nich wolnego czasu i uczulał ich na wzajemną pomoc w nauce. Starał się nie tylko zaszczepić w nich uczucia estetyczne, ale nie stronił od kontaktu pozaszkolnego z nimi. Niewątpliwie z jednej strony wynikało to z ogólnych wytycznych pedagogiki I połowy XX wieku, z drugiej jednak - analiza podobnych sprawozdań pisanych przez innych nauczycieli pozwala wysnuć wniosek, że tak naprawdę tylko wyjątki wśród grona pedagogicznego stosowały się do nowych wymogów większego kontaktu nauczycieli z uczniami. Do nich należał Stefan Grabiński.

Również podejście pisarza do obowiązków administracyjnych w szkole stawia w zupełnie innym niż dotychczas świetle jego działalność nauczycielską. Uczestniczył we wszystkich konferencjach nauczycielskich, które zostały utrwalone w dokumentach szkolnych

\footnotetext{
28 Ibidem, sprawa 1166

29 Ibidem, sprawa 1165.
}

\section{7}




\section{Sprawozdanie \\ Grabińskiego z czynności \\ wychowawczych \\ z 8 IV 1927 r.}

Ze zbiorów Centralnego

Państwowego Historycznego

Archiwum we Lwowie

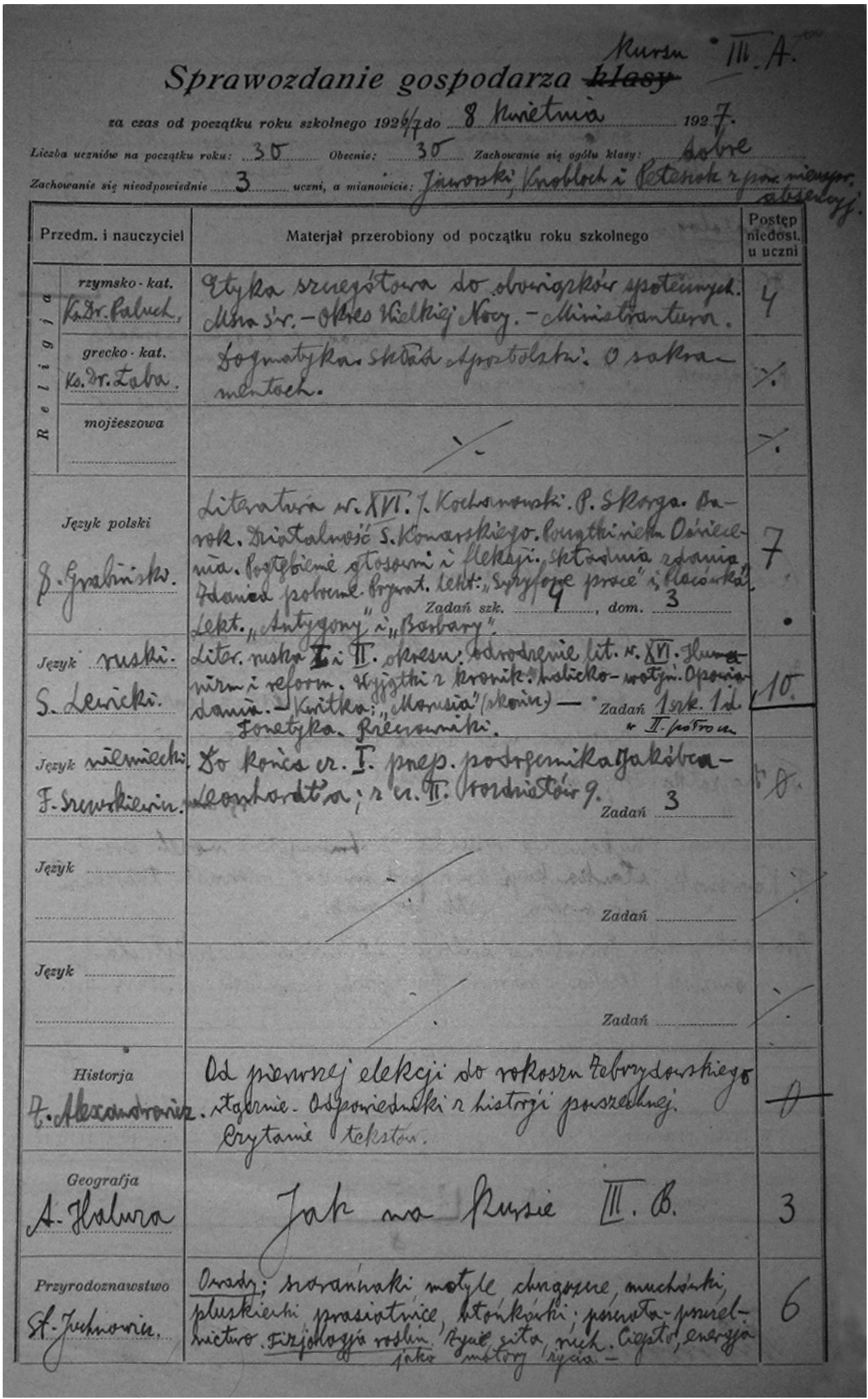




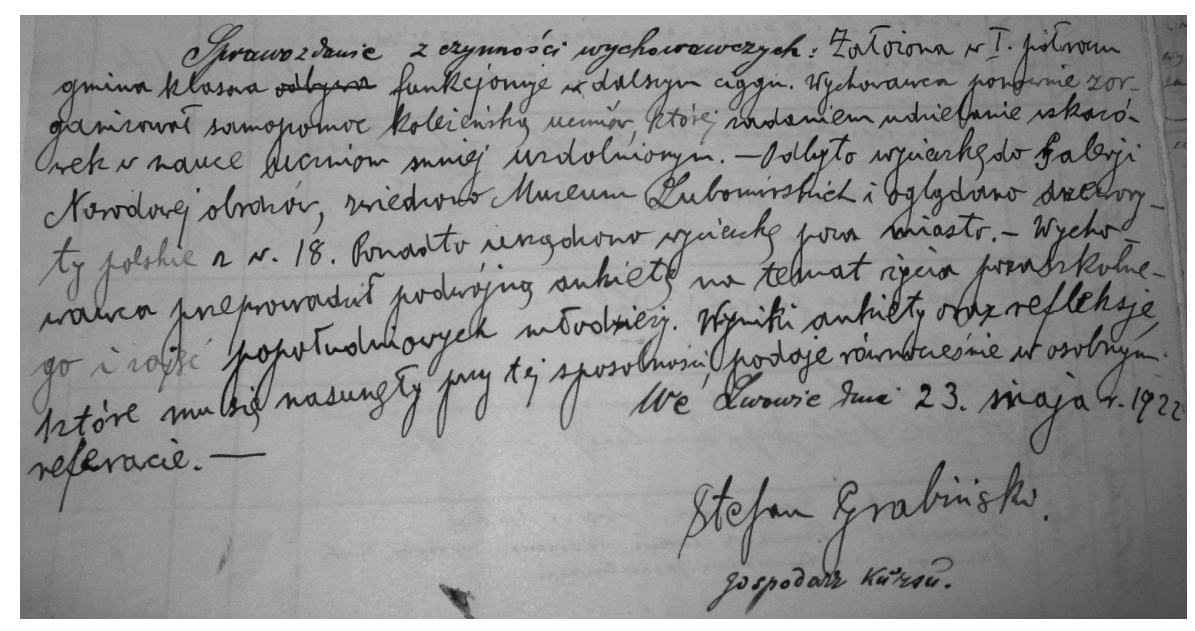

\section{Sprawozdanie \\ Grabińskiego z czynności wychowawczych z 8 IV 1927 r.}

Ze zbiorów Centralnego Państwowego Historycznego Archiwum we Lwowie

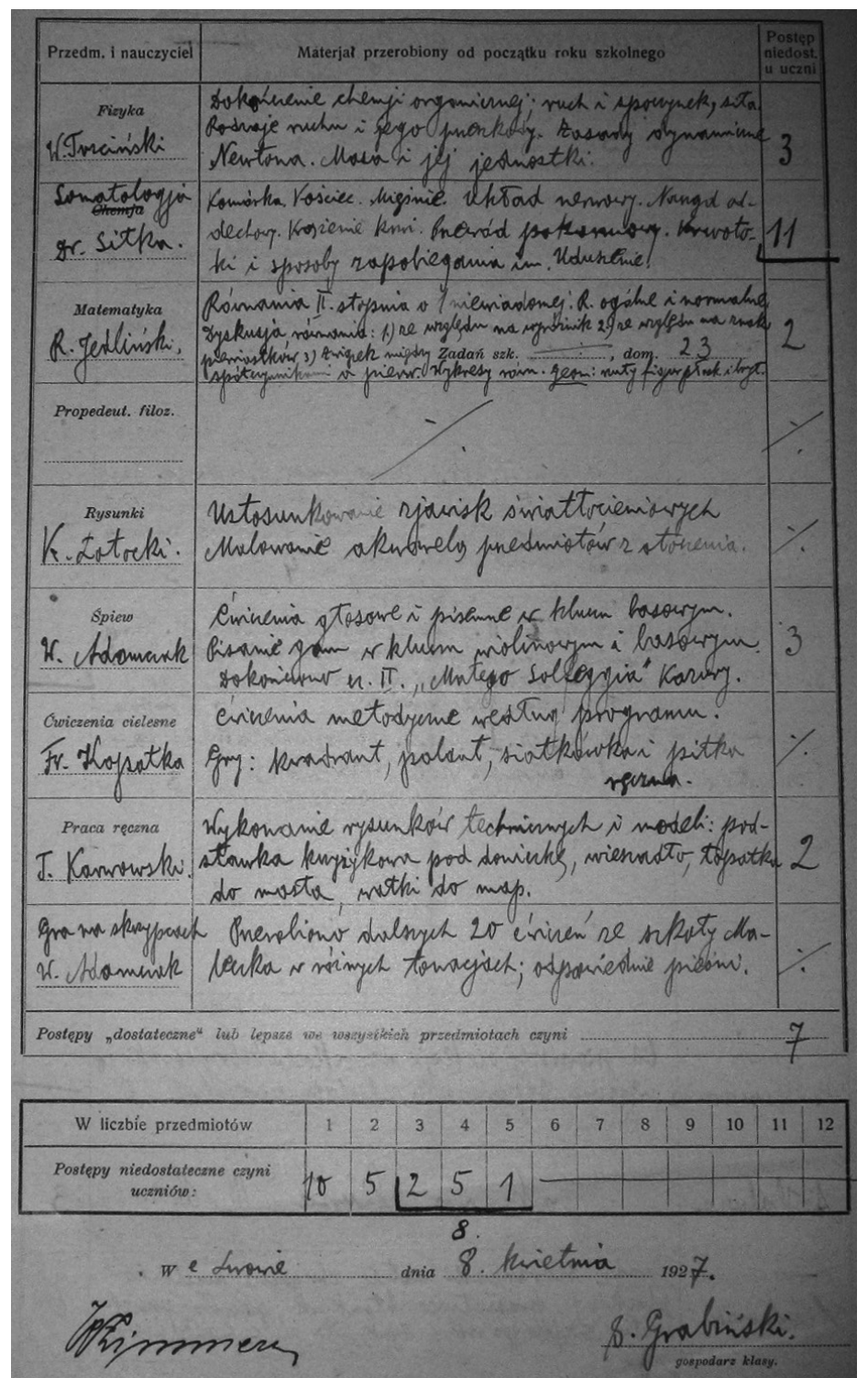


za jego czasów ${ }^{30}$, jakkolwiek zwykle nie zabierał głosu w trakcie ich trwania. Przykładowo 23 V 1923 roku wypowiadał się w sprawie ankiet uczniów dotyczących spędzania przez nich wolnego czasu oraz w sprawie samopomocy i wycieczek pozaszkolnych. Tego samego dnia poparł wniosek o nadanie szkole imienia ks. Stanisława Konarskiego. Ostatecznie Rada Pedagogiczna za nowej dyrekcji zmieniła zdanie i 10 XI 1926 roku uchwalono jednogłośnie wniosek prof. Stanisława Juchnowicza, aby patronem szkoły został niedawno zamordowany kurator Stanisław Sobiński. 24 XI dyrektor Zimmerman wystosowal pismo do kuratorium lwowskiego, aby poparło ono starania Rady Pedagogicznej i ostatecznie to Sobiński został patronem szkoły.

Jednak najbardziej widoczny był Grabiński podczas konferencji 12 XII 1925 roku, kiedy wygłosił referat Metodyczna analiza utworu Adama Mickiewicza pt. „Upiór” oraz związanych z nim zagadnień z II i IV części „Dziadów” i we fragmentach części I. Niestety, referatu nie udało się odnaleźć. A szkoda, gdyż wpisuje się on w zainteresowania naukowe i twórcze Grabińskiego. Dyrektor Zimmerman tak scharakteryzował tę prelekcję:

Referent wyjaśnił w części I odczytu związek między balladą a Dziadami i na tym tle wyttumaczyl, jak należy pojmować zjawienie się Gustawa w części II (w kaplicy) i IV-tej; w części zaś drugiej przeprowadził metodyczny rozbiór, wreszcie przeczytał dwa wypracowania uczniów, które były ilustracją, jak uczniowie rzecz tę rozumieli.

Po referacie - na zapytania kolegów - udzielał p. Grabiński wyjaśnień na poszczególne kwestie. Dyrektor imieniem Rady podziękował p. Referentowi za ten referat, tak bardzo zajmujący i budzący tyle nowych myśli, a przeprowadzający rozbiór metodyczny w sposób oryginalny i skuteczny, czego dowodem są odczytane wypracowania uczniów ${ }^{31}$.

Referat potwierdza zainteresowania naukowe pisarza i jego wielkie znawstwo w tematyce wampiryzmu, okultyzmu itp., które potrafil połączyć odpowiednio nie tylko ze swoją dzialalnością literacką, ale i dydaktyczną.

Pomimo sumiennego wypełniania obowiązków nauczycielskich i ugruntowanej pozycji w szkole, druga połowa lat 20. była w biografii Grabińskiego niekorzystna. Był to okres po rozejściu się z żoną i powrotu do domu matki, kiedy pisarz coraz wyraźniej odchodził w „niepamięć” publiczności literackiej. Odbijało się to na jego dochodach, stąd „chwytał się" dodatkowych zajęć szkolnych. Przykładowo w roku szkolnym 1927/28 uczył również - poza macierzystym miejscem pracy - w Prywatnym Gimnazjum Żeńskim Konwentu Sióstr Sercanek we Lwowie ${ }^{32}$. Nadmiar pracy zawodowej odbijał się na jego zdrowiu. Abstrahując od wielu innych czynników, mogło to być również spowodowane kiepskimi warunkami lokalowymi seminarium. Prawdopodobnie problemy były tak poważne, że Grabiński starał się o uzyskanie dłuższego urlopu zdrowotnego, a w konsekwencji - o przejście na wcześniejszą emeryturę. Kiedy w czerwcu 1929 roku doprowadził kurs V b, gdzie był wychowawcą, do matury, kuratorium zgodziło się na urlop. Ostatni podpis Grabińskiego w dokumentach szkolnych widnieje pod sprawozdaniem wychowawcy z 28 VI 1929 roku.

\footnotetext{
30 Lista niepełna. Ta jednak obejmuje konferencje nauczycielskie, podczas których Grabiński bez żadnych wątpliwości był obecny: 1 IX 1921, 23 V 1923, 23 X 1923, 17 XII 1923, 1 II 1924, 28 VI 1924, 20 XII 1924, 31 I 1925, 22 VI 1925, 1 IX 1925, 22 IX 1925, 20 XI 1925, 12 XII 1925, 10 XI 1926, 28 VI 1929.

31 CDIAU we Lwowie, fond 179, opis 3, sprawa 1165.

32 Ibidem, sprawa 55.
} 
Od września 1929 polonistą w seminarium w zastępstwie Grabińskiego został Zygmunt Jewarczykowski ${ }^{33}$.

Trudno zarzucać Arturowi Hutnikiewiczowi, że w swej biografii Stefana Grabińskiego nie zajął się szerzej jego działalnością nauczycielską. Wszak już sam tytuł wskazuje, że autora monografii interesowała nade wszystko twórczość literacka. Jednakże projekcja swojego krótkiego kontaktu z pisarzem w trakcie lat szkolnych na całokształt postaci Grabińskiego nauczyciela spowodowała, że Hutnikiewicz przyczynił się do powstania mitu pisarza choleryka, a przy tym samotnika, który w żaden sposób nie przystawał do ówczesnych warunków szkolnych. Okazuje się jednak, że mimo swej nerwowości i introwertyczności Grabiński był cenionym pedagogiem o szerokiej wiedzy merytorycznej i dużych umiejętnościach dydaktycznych. Potwierdzają to zarówno lata pracy w szkołach przemyskich, jak i lwowskich.

33 Ibidem, sprawa 1166.

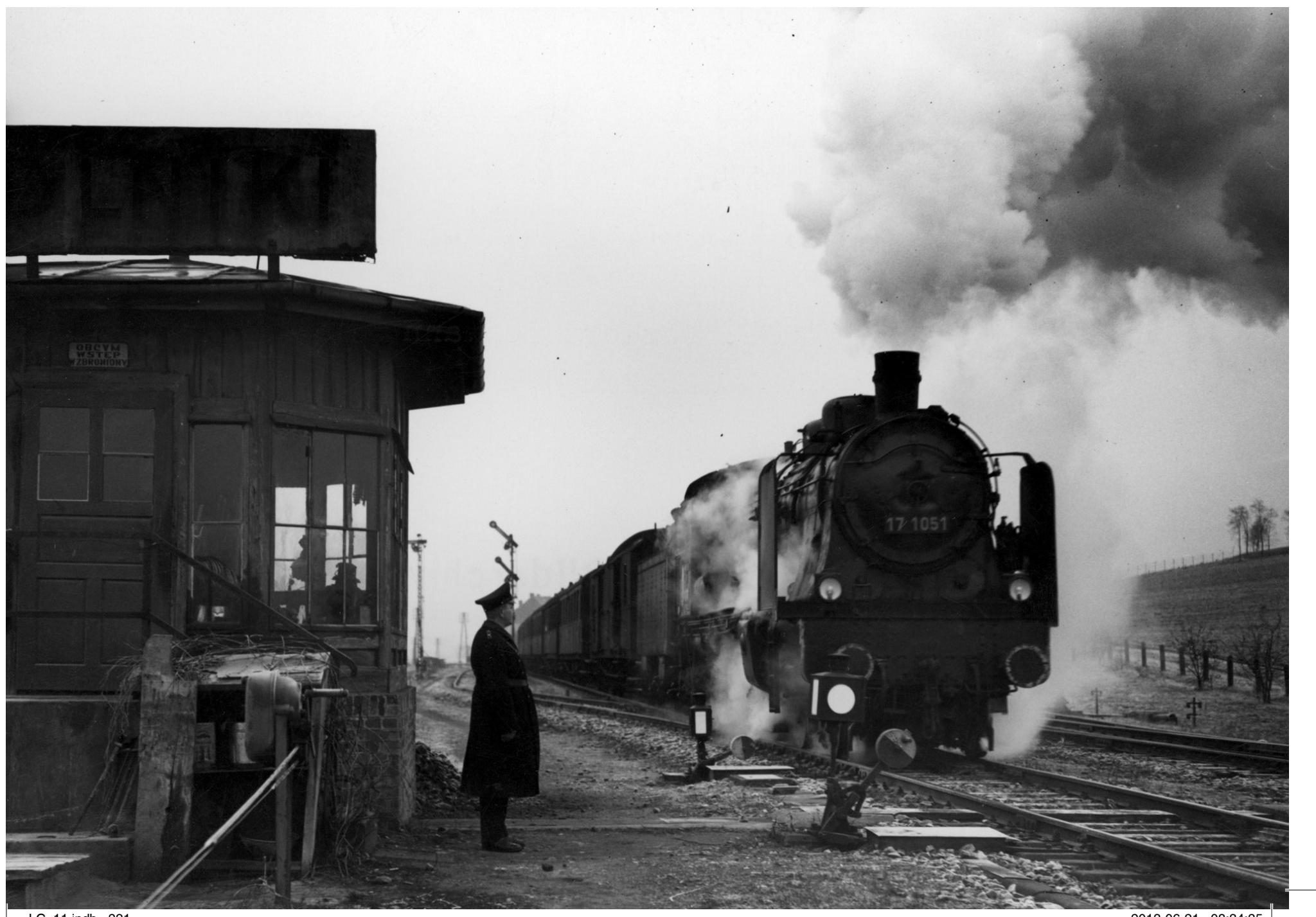

